\title{
SHIP-Deficient Mice Develop Spontaneous Intestinal Inflammation and Arginase-Dependent Fibrosis
}

\author{
Keith W. McLarren, ${ }^{\star \dagger}$ Alexandra E. Cole,${ }^{* \dagger}$ \\ Shelley B. Weisser, ${ }^{* \dagger}$ Nicole S. Voglmaier, ${ }^{\star \dagger}$ \\ Victoria S. Conlin, ${ }^{* \dagger}$ Kevan Jacobson, ${ }^{* \dagger}$ \\ Oana Popescu, ${ }^{*}$ Jean-Luc Boucher, ${ }^{\ddagger}$ and \\ Laura M. Sly ${ }^{\star}$ \\ From the Division of Gastroeneterology, Department of Pediatrics, \\ BC Children's Hospital, Vancouver, British Columbia, Canada; the \\ Division of Gastroeneterology, ${ }^{\dagger}$ Department of Pediatrics, The \\ University of British Columbia, Vancouver, British Columbia, \\ Canada; and the Université Paris Descartes, ${ }^{\ddagger}$ Paris, France
}

Intestinal fibrosis is a serious complication of Crohn's disease (CD) that can lead to stricture formation, which requires surgery. Mechanisms underlying intestinal fibrosis remain elusive because of a lack of suitable mouse models. Herein, we describe a spontaneous mouse model of intestinal inflammation with fibrosis and the profibrotic role of arginase I. The Src homology 2 domain-containing inositol polyphosphate $5^{\prime}$-phosphatase-deficient $\left(\mathrm{SHIP}^{-1}\right)$ mice developed spontaneous discontinuous intestinal inflammation restricted to the distal ileum starting at the age of 4 weeks. Mice developed several key features resembling $\mathrm{CD}$, including inflammation and fibrosis. Inflammation was characterized by abundant infiltrating Gr-1-positive immune cells, granuloma-like immune cell aggregates that contained multinucleated giant cells, and a mixed type 2 and type 17 helper T-cell cytokine profile. Fibrosis was characterized by a thickened ileal muscle layer, collagen deposition, and increased fibroblasts at the sites of collagen deposition. SHIP $^{-/}$ilea had increased arginase activity and arginase I expression that was inversely proportional to nitrotyrosine staining. $\mathrm{SHIP}^{-1-}$ mice were treated with the arginase inhibitor $S$-(2-boronoethyl)L-cysteine, and changes in the disease phenotype were measured. Arginase inhibition did not affect the number of immune cell infiltrates in the $\mathrm{SHIP}^{-1-}$ mouse ilea; rather, it reduced collagen deposition and muscle hyperplasia. These findings suggest that arginase activity is a potential target to limit intestinal fibrosis in patients with CD. (Am J Pathol 2011, 179:180-188; DOI: 10.1016/j.ajpath.2011.03.018)
Inflammatory bowel disease includes two major presentations of intestinal disease: Crohn's disease (CD) and ulcerative colitis. Both are characterized by chronic, relapsing and remitting, or progressive inflammation of the intestine. Patients experience severe intestinal pathological conditions that cause physical symptoms, including pain, nausea, and diarrhea. ${ }^{1}$ Ulcerative colitis is restricted to the colon, whereas CD can occur in any part of the gastrointestinal tract. ${ }^{2}$

Intestinal fibrosis is a serious complication of CD. It can lead to strictures and stenoses that narrow the lumen of the intestine and can cause dangerous obstructions. Approximately one in three people with CD develops strictures within 10 years of diagnosis and requires surgery to remove the diseased bowel. The most common site of surgical resection in patients with $C D$ is the distal ileum. ${ }^{3,4}$ Furthermore, patients who have undergone surgery for fibrosis frequently relapse, developing intestinal inflammation and fibrotic strictures at the same location as the previous resection. ${ }^{5}$ Anti-tumor necrosis factor- $\alpha$ therapy is effective at reducing inflammation in active CD, but the current thinking is that it is not effective at reducing fibrosis or fibrogenic gene expression. ${ }^{6-9}$ To our knowledge, there are no antifibrotic drugs available for use in patients with CD. ${ }^{10}$

Fibrosis can be considered a pathological consequence of an excessive healing response. Normally, in response to tissue injury, the healing process includes the deposition of extracellular matrix proteins, the most abundant of which are members of the collagen family. ${ }^{11}$ Thus, some degree of mild subclinical fibrosis may occur

Supported by a Canadian Association of Gastroenterology (CAG) summer studentship (A.E.C.), a Crohn's and Colitis Foundation of Canada grant in aid of research (L.M.S.), and a CAG/Canadian Institutes of Health Research/Crohn's and Colitis Foundation of Canada new investigator award (L.M.S.).

Accepted for publication March 21, 2011.

Supplemental material for this article can be found at http://ajp. amjpathol.org or at doi: 10.1016/j.ajpath.2011.03.018.

Address reprint request to Laura M. Sly, Ph.D., Room A5-142, Translational Research Bldg, Child and Family Research Institute, $950 \mathrm{~W} 28^{\text {th }}$ Ave, Vancouver, British Columbia, Canada V5Z 4H4. E-mail: laurasly@ interchange.ubc.ca. 
in all patients with CD. ${ }^{12,13}$ The cell types that contribute to scar formation are mesenchymal cells, including myofibroblasts, smooth muscle cells, and fibroblasts. ${ }^{4} \mathrm{~Pa}$ tients with $\mathrm{CD}$ and fibrosis experience accumulation of fibroblasts through the gut wall. ${ }^{14}$

Despite the urgent need to prevent or treat intestinal stricturing in patients with $C D$, little is known about the mechanisms underlying this process, in part because of a lack of suitable animal models for the study of intestinal fibrosis. There are many mouse models of intestinal inflammation, ${ }^{15,16}$ but studies ${ }^{17-22}$ of intestinal fibrosis have been limited to six colitis models. There are two genetic mouse models of spontaneous intestinal inflammation in the distal ileum: transgenic tumor necrosis factor $^{\triangle A R E}$ and SAMP1/YitFc mice. ${ }^{23,24}$ (SAMP1/YitFC mice are a subline of the senescence-accelerated mouse line.) Both of these models recapitulate some features of $C D$ and have been used to study the development of chronic ileitis. The SAMP1/YitFc mouse is reported to develop fibrostenotic strictures at the age of 40 weeks $^{24}$ but has not been used as a model for the treatment of intestinal fibrosis.

The Src homology 2 domain-containing inositol polyphosphate $5^{\prime}$-phosphatase (SHIP) is a hematopoietic-specific negative regulator of the phosphatidylinositol3-kinase (PI3K) pathway. It removes the $5^{\prime}$ phosphate group from class IA PI3K-generated phosphatidylinositol 3,4,5-triphosphate, removing this important second messenger from the cell membrane, thereby discontinuing PI3K activity. SHIP $\mathrm{P}^{-/-}$mice were generated in 1998 by the laboratories of Krystal, Humphries, and colleagues. ${ }^{25}$ $\mathrm{SHIP}^{-/-}$mice have a myeloproliferative disorder, with a twofold to threefold increase in myeloid cells at different sites, lung pathological features, and a shortened life span. ${ }^{25}$ Myeloid cells from these mice are hyperresponsive to various stimuli, ${ }^{26}$ and in vivo differentiated $\mathrm{SHIP}^{-/-}$ macrophages are alternatively activated and constitutively express arginase I (Argl). ${ }^{27}$ Recently, $\mathrm{SHIP}^{-1-}$ mice were reported to develop spontaneous intestinal CD-like inflammation. ${ }^{28}$

Herein, we confirm and extend these findings describing the inflammatory infiltrates, cytokine responses, and specific features that define ileal fibrosis. $\mathrm{SHIP}^{-1-}$ mice develop thickened muscle layers, have increased collagen deposition, and accumulate fibroblasts in the affected ileum. In addition, the $\mathrm{SHIP}^{-1-}$ mouse ilea have increased Argl expression and arginase activity. More importantly, treating $\mathrm{SHIP}^{-1-}$ mice with the arginase inhibitor, S-(2-boronoethyl)-L-cysteine (BEC), reduced ileal muscle hyperplasia and collagen deposition. These findings identify arginase activity as a novel therapeutic target for the treatment of intestinal fibrosis in CD.

\section{Materials and Methods}

\section{Mice}

SHIP heterozygotes, an F2 generation of C57BL/6 $\times$ 129Sv mice, were bred to generate $\mathrm{SHIP}^{+/+}$and $\mathrm{SHIP}^{-/-}$ littermates. Mice were maintained in sterilized filter-top cages and fed autoclaved food and water under specific pathogen-free conditions at the Animal Care Facility at the Child \& Family Research Institute (Vancouver, BC). Sentinel mice were routinely screened for pathogens using a comprehensive serological profile service (Radil, Columbia, MO). All mice used were between the ages of 4 and 16 weeks. Experimentation was performed in accordance with institutional and Canadian Council on Animal Care guidelines.

\section{Histological Characteristics}

Mouse tissues were fixed in 10\% neutral-buffered formalin at $4^{\circ} \mathrm{C}$ for 24 hours before paraffin processing. Paraffin sections $(5-\mu \mathrm{m}$ thick) were stained with $\mathrm{H} \& \mathrm{E}$ for histological examination. Masson's trichrome staining was performed according to the manufacturer's instructions (Sigma, St Louis, MO). Images were acquired and analyzed using a Zeiss Axiovert 200 microscope, a Zeiss AxiocamHR camera, and the Zeiss Axiovision 4.0 software imaging system.

\section{Histological Analyses}

Crypt depth and villus length were determined by counting epithelial cell nuclei from the base of crypts to the crypt-villus junction and from the crypt-villus junction to the villus tip, respectively, on uniform horizontal cross sections of crypts and villi. Goblet cells per crypt-villus were counted from the base of the crypt to the tip of the villus. Representative crypts-villi (10 per mouse) were counted in 5 to $10 \mathrm{H} \&$ E-stained sections of distal ileum for six 8-week-old $\mathrm{SHIP}^{+/+}$and $\mathrm{SHIP}^{-/-}$mice by two individuals blinded to genotype (K.W.M. and A.E.C.). To count immune cell infiltrates, four representative fields of H\&Estained cross sections of seven untreated and seven BEC-treated $\mathrm{SHIP}^{-1-}$ mouse ilea were obtained at $\times 20$ magnification; infiltrates were counted according to nuclear morphological features in the circular muscularis externa and submucosa. The thickness of the muscularis externa from the serosa to the muscularis mucosa was measured at six points in 10 cross sections of distal ileum from seven untreated and seven BEC-treated $\mathrm{SHIP}^{-1-}$ mice. In all cases, sections were nonconsecutive, separated by at least $50 \mu \mathrm{m}$, and counted at $\times 20$ magnification.

\section{IHC Procedures}

For detection of CD3, F4/80, Gr-1/Ly6, Argl, and nitrotyrosine slide-mounted $5-\mu \mathrm{m}$ sections of FFPE tissues were deparaffinized and rehydrated. For CD3 and Argl detection, heat-induced epitope retrieval was performed by immersing the slides in $1 \mathrm{mmol} / \mathrm{L}$ EDTA $(\mathrm{pH} 8.0)$ at $95^{\circ} \mathrm{C}$ for 20 minutes and allowing them to cool to room temperature. For F4/80, Gr-1, and nitrotyrosine detection, enzyme-induced epitope retrieval was performed by incubating samples with $20 \mu \mathrm{g} / \mathrm{mL}$ proteinase K in PBS for 15 minutes at room temperature. All slides were rinsed thoroughly in Tris-buffered saline with $0.1 \%$ Tween 20 . Endogenous peroxidase activity was blocked with 1.5\% $\mathrm{H}_{2} \mathrm{O}_{2}$ in PBS for 10 minutes. Endogenous avidin and 
biotin were blocked with an avidin-biotin blocking kit, according to the manufacturer's instructions (Vector Laboratories, Burlingame, CA). The primary antibodies used were rabbit anti-CD3 (Abcam, Cambridge, MA), rat antiGr-1 (Acris Antibodies, Herford, Germany), rat anti-F4/80 (AbD Serotec, Oxford, UK), mouse anti-Argl (BD Biosciences, Mississauga, $\mathrm{ON}$ ), and mouse anti-nitrotyrosine (Millipore, Billerica, MA). Blocking buffers, biotinylated secondary antibodies, and avidin-biotin-horseradish peroxidase or alkaline phosphatase complexes were prepared and used from rabbit IgG, rat IgG, or mouseon-mouse immunohistochemistry (IHC) detection kits, according to the manufacturer's instructions (Vector Laboratories). Signals were detected with a diaminobenzidine chromogen system (Dako, Carpinteria, CA) or Vector Red (Vector Laboratories), and developed sections were counterstained with Harris' hematoxylin (Sigma). For vimentin staining, fresh tissue was flash frozen in dry ice-isopentane and embedded in optimal cutting temperature compound (Sakura Finetech; VWR Canada, Mississauga). Thaw-mounted sections were fixed in ice-cold acetone and blocked with the Mouseon-Mouse detection system. Sections were incubated with mouse anti-vimentin antibody (BD Biosciences), followed by secondary Alexa 568-conjugated goat anti-mouse IgG antibody (Molecular Probes/Invitrogen, Eugene, OR). Sections were mounted in Vectashield mounting medium with DAPI (Vector Laboratories). Negative controls omitted primary antibodies and were performed for all antibodies.

\section{Mouse Cytokine Arrays}

Mouse-specific cytokine levels were determined in 150-mg samples of ilea from $\mathrm{SHIP}^{+/+}$mice and inflamed ilea from SHIP ${ }^{-/-}$mice ( $n=4$ per group) using the Mouse Cytokine Array Panel A kit from R\&D Systems (Minneapolis, MN), according to the manufacturer's instructions. Protein (200 $\mu \mathrm{g}$ ) was used for each array. Spot densities were quantified using ImageJ software version 1.43 (http://rsbweb.nih.gov/ ij/index.htm/) and exported to GraphPad Prism 5 version 5 (GraphPad Software Inc., San Diego, CA). Spot densities were corrected for individual background to diminish interarray variations.

\section{Sircol Assays}

Sections of fresh mouse distal ileum (30 to $100 \mathrm{mg}$ ) were minced with surgical scissors in $500 \mu \mathrm{L}$ of $0.5 \mathrm{~mol} / \mathrm{L}$ acetic acid with $10 \mathrm{mg} / \mathrm{mL}$ pepsin and agitated (at 1000 rpm with a VWR microplate shaker) overnight at room temperature. Tissue debris was removed and collagen was measured by the Sircol soluble collagen assay (Biocolor Ltd, Carrickfergus, UK), according to the manufacturer's instructions.

\section{Arginase Assays}

Fresh tissue samples were collected and homogenized in 1-mL arginase lysis buffer using a Polytron MR2100 bench-top homogenizer. Homogenates were cleared by centrifugation at $16,000 \times g$ for 10 minutes at $4^{\circ} \mathrm{C}$. Arginase activity was determined indirectly by measuring the concentration of urea generated by the arginase-dependent hydrolysis of L-arginine, as previously described. ${ }^{29}$

\section{Mouse Treatment with BEC}

BEC was synthesized by Dr Jean-Luc Boucher (Université Paris Descartes, Paris, France), as previously described. ${ }^{30} \mathrm{BEC}$ was dissolved in deionized distilled water, adjusted to $\mathrm{pH}$ 7, and filter sterilized. BEC (100 $\mu \mathrm{L}$ of a $0.2 \%$ solution) was administered daily by oral gavage to 4-week-old SHIP ${ }^{-/}$mice for 2 weeks.

\section{Statistical Analyses}

Unpaired two-tailed Student's $t$-tests were performed when indicated using GraphPad Prism version 5 (GraphPad Software Inc.). For multiple comparisons made during cytokine assays, the Bonferroni correction was applied. Differences were considered significant at $P<0.05$.

\section{Results}

\section{SHIP $P^{-1-}$ Mice Have Spontaneous Intestinal Inflammation Resembling $C D$}

In our work with $\mathrm{SHIP}^{-/-}$mice, we found that adult $\mathrm{SHIP}^{-1-}$ mice consistently showed spontaneous intestinal inflammation. In situ intestines were thick and opaque (Figure 1A). This phenotype was restricted to the distal third of the ileum and usually within $10 \mathrm{~cm}$ of

A
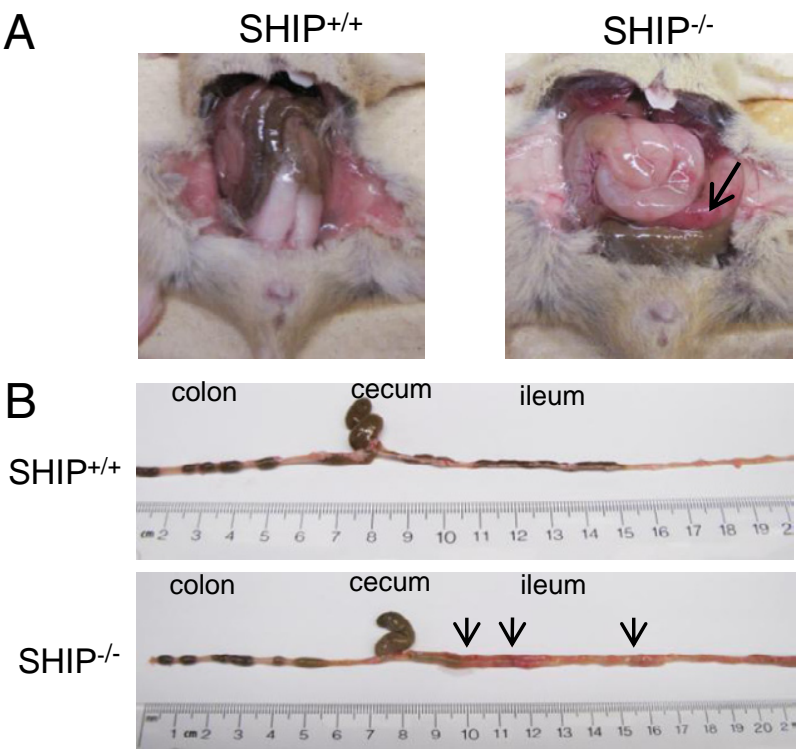

Figure 1. $\mathrm{SHIP}^{-/-}$mice develop spontaneous intestinal inflammation. A: The ilea of 6-week-old SHIP $^{+/+}$and SHIP $^{-/}$mice were compared in situ. SHIP $^{-/-}$ mice have thickened intestines with patchy inflammation (arrow). B: On extraction and extension of each ileum, it was determined that inflammation in the SHIP ${ }^{-/}$mice was restricted to the distal ileum. Arrows indicate sites of inflammation. 
A
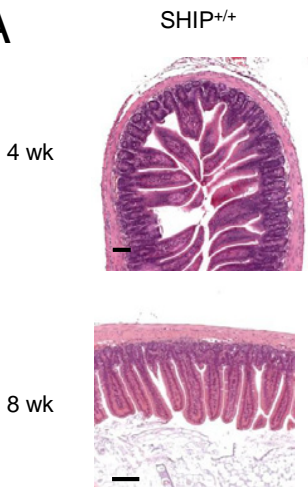

SHIP -1
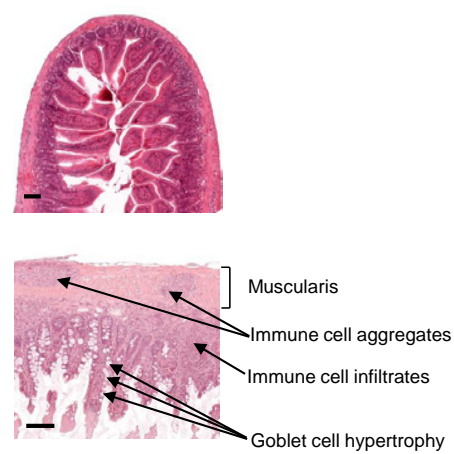

B
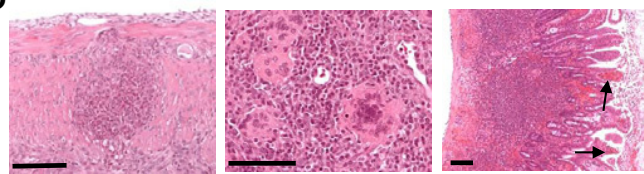

Figure 2. Intestinal inflammation in $\mathrm{SHIP}^{-/-}$mice develops between the ages of 4 and 8 weeks (wk) and is histologically similar to CD. A: H\&E analysis of $\mathrm{SHIP}^{+/+}$and $\mathrm{SHIP}^{-/-}$ilea at $4 \mathrm{wk}$ (top) revealed no signs of pathological features in either mouse group. At the age of $8 \mathrm{wk}$ (bottom), the ilea of $\mathrm{SHIP}^{-/-}$mice revealed thickening of the muscularis, immune cell aggregates and infiltrates, and goblet cell hypertrophy. Scale bar $=100 \mu \mathrm{m}$. B: $\mathrm{SHIP}^{-/-}$mice (aged $8 \mathrm{wk}$ ) shared additional histopathological features with $\mathrm{CD}$, including immune cell aggregates that are organized into poorly formed granuloma-like structures in the muscularis (left) and contain multinucleated giant cells (middle); the ilea revealed signs of bleeding into the lumen (arrows, right). Sections are representative of 12 individual mice examined at the age of 6 to $8 \mathrm{wk}$. Scale bars: $100 \mu \mathrm{m}$ (left and middle); 500 $\mu \mathrm{m}$ (right).

the ileocecal junction (Figure 1B). Discontinuous patches of active inflammation were visible as areas of redness on the gut wall (Figure 1, A and B).

The onset of the spontaneous intestinal inflammation was determined by H\&E staining to occur between the ages of 4 and 8 weeks. At the age of 4 weeks, SHIP ${ }^{-/}$ mouse ilea showed no histopathological features (Figure 2A). However, inflammation was present in all $\mathrm{SHIP}^{-1-}$ mice from the age of 6 weeks onward (data not shown). By 8 weeks, the ilea of the $\mathrm{SHIP}^{-1-}$ mice showed thickened muscularis externa, especially the circular muscle layer, goblet cell hypertrophy, and immune cell infiltrates and aggregates throughout the gut wall (Figure 2A, bottom right). Immune cell aggregates were identified as poorly or partially formed granuloma-like structures (Figure 2B, left) and contained multinucleated giant cells (Figure 2B, middle). There was also evidence of bleeding into the lumen of the gut (Figure 2B, right). In addition, $\mathrm{SHIP}^{-/-}$mouse ilea showed epithelial cell hyperplasia (see Supplemental Figure S1 at http://ajp.amjpathol.org). SHIP ${ }^{-1-}$ mouse histopathological features were restricted to the ileum because colons and ceca appeared normal (see Supplemental Figure S2 at http://ajp.amjpathol.org).

\section{Villi and Lymphoid Aggregates Contain Abundant Gr-1/Ly6 $6^{+}$Granulocytes}

Having established that $\mathrm{SHIP}^{-/-}$mice have increased ileal inflammation, we analyzed the immune cell infil- trates and immune cell aggregates in the $\mathrm{SHIP}^{-/-}$ilea. Fixed sections were stained by $\mathrm{IHC}$ to detect granulocytes/ monocytes $\left(\mathrm{Gr}^{+}\right)$, macrophages $\left(\mathrm{F} 4 / 80^{+}\right)$, and $\mathrm{T}$ cells $\left(\mathrm{CD}^{+}\right)$. Gr- $1^{+}$cells were present through the entire thickness of the gut wall and were abundant in immune cell infiltrates and immune cell aggregates (Figure 3). Gr-1 ${ }^{+}$ cells had multilobed nuclei, suggesting that they are neutrophils (Figure 3 ). There were a few $\mathrm{F} 4 / 80^{+}$macrophages within immune cell aggregates (see Supplemental Figure S3 at $h$ ttp://ajp.amjpathol.org). There were a few $\mathrm{CD}^{+} \mathrm{T}$ cells within crypts and villi (see Supplemental Figure S4 at http://ajp.amjpathol.org). The absence of abundant T cells within the SHIP ${ }^{-1-}$ ilea was unexpected but is consistent with a recent report. ${ }^{28}$

\section{SHIP ${ }^{-1-}$ Mouse Inflamed llea Have Increased Type 2 and Type 17 Helper T-Cell Cytokines}

To describe the type of inflammation in the $\mathrm{SHIP}^{-1}$ mouse ileum, relative cytokine levels present in ileal tissue homogenates from 8-week-old $\mathrm{SHIP}^{-/-}$mice were compared with those in $\mathrm{SHIP}^{+/+}$littermate controls. SHIP ${ }^{-/}$mouse ileal homogenates had significantly increased levels of type 2 helper T-cell (Th2) cytokines, IL-4, and IL-13, but there was no difference in IL-5 (Figure 4A). SHIP ${ }^{-1-}$ ilea had increased IL-23 (Th17) but no difference in IL-17 (Figure 4B). The levels of Th1 cytokines, IL-12p70, and interferon- $\gamma$ were also the same between the two groups (Figure 4C).

\section{SHIP ${ }^{-1-}$ Mice llea Have More Collagen}

Because $\mathrm{SHIP}^{-/-}$mouse ilea were thick and inflexible, we examined them for evidence of fibrosis. H\&E staining revealed a thickened muscle layer in 8-week-old $\mathrm{SHIP}^{-1-}$ mice compared with $\mathrm{SHIP}^{+1+}$ littermate controls (Figure 5A). Masson's trichrome stain for fibrosis in adjacent sections showed abundant collagen (blue)
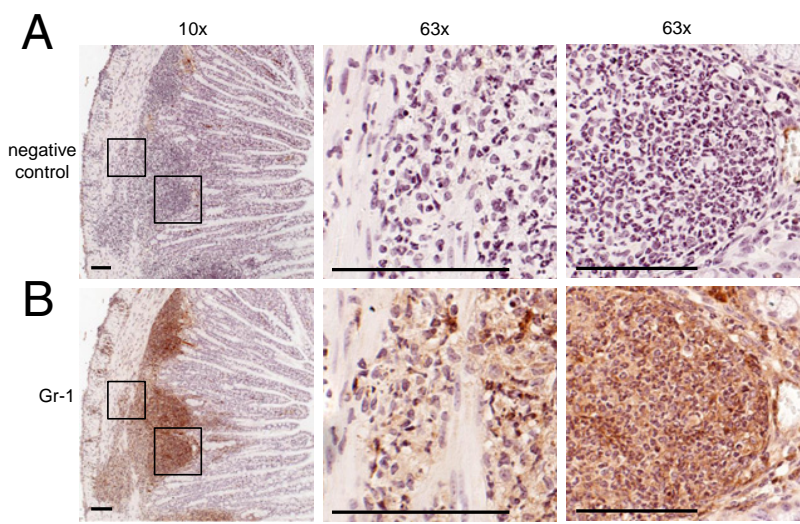

Figure 3. Immune cell aggregates and infiltrates from 8 -week-old $\mathrm{SHIP}^{-/}$ mice are predominantly $\mathrm{Gr}-1^{+}$. A: $\mathrm{IHC}$ anti-Gr-1 antibody-negative control. B: Gr-1-stained serial section (brown). Gr- $1^{+}$cells were present through the entire thickness of the gut wall (hematoxylin, blue). IHC staining is shown at $\times 10$ magnification (left). Insets (defined): $\times 63$ magnification of immune cell infiltrates in the muscularis (middle) and in immune cell aggregates (right). Multilobed nuclear morphological features are visible at $\times 63$ magnification. Scale bars $=50 \mu \mathrm{m}$. Sections are representative of 12 mice. 
A

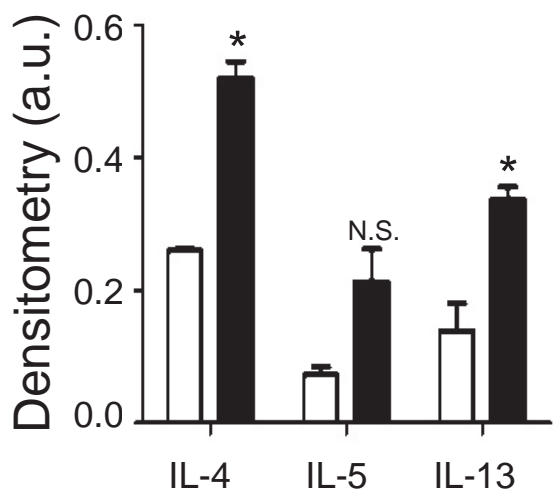

B

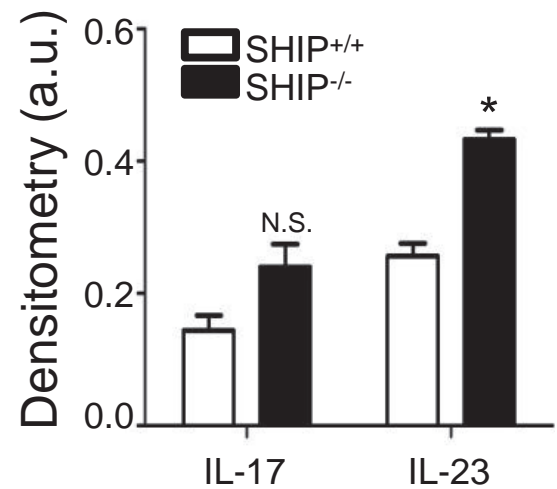

C

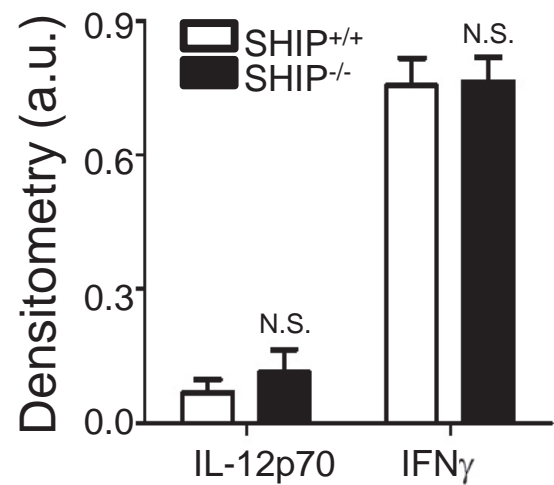

Figure 4. $\mathrm{SHIP}^{-/-}$mouse ileal cytokine expression shows a mixed Th2-Th17 profile. Cytokine levels were measured in 8 -week-old SHIP ${ }^{+/+}$and SHIP $^{-/}$ mice ileal homogenates. Protein $(200 \mu \mathrm{g})$ was analyzed for IL-4, IL-5, IL-13, IL-17, IL-23, IL-12p70, and interferon (IFN)- $\gamma$ expression levels. Graphs show tissue expression levels of representative Th2 (A), Th17 (B), and Th1 (C) cytokines, expressed as mean \pm SD signal intensity for four mice per group. IL-4, IL-13, and IL-23 were significantly increased in SHIP ${ }^{-/}$mice ilea compared with SHIP ${ }^{+/+}$littermate controls. No significant (N.S.) differences were observed for IL-5, IL-17, IL-12p70, or IFN- $\gamma$. ${ }^{*} P<0.05$ comparing $\mathrm{SHIP}^{+/+}$ with $\mathrm{SHIP}^{-/-}$mice ilea using a Student's $t$-test with Bonferroni correction. a.u. indicates arbitrary unit.

present in the submucosa and between muscle layers in the $\mathrm{SHIP}^{-1-}$ mouse ilea (Figure 5B). However, given the larger overall size of the $\mathrm{SHIP}^{-1-}$ mouse ilea, we measured the collagen per milligram of tissue. Sircol assays for soluble collagen were performed comparing SHIP ${ }^{-/-}$with SHIP ${ }^{+/+}$distal ilea. SHIP ${ }^{-/-}$mouse ilea had 2.1-fold more collagen than age-matched $\mathrm{SHIP}^{+/+}$ control mouse ilea, with significant differences at the ages of 6 to 8 and 10 to 12 weeks (Figure 5C).

SHIP ${ }^{-1}$ Mice llea Have More Vimentin ${ }^{+}$ Fibroblasts, Increased Argl, and Arginase Activity

Because fibroblasts are key players in intestinal fibrosis, we compared the numbers of fibroblasts present in the ilea of $\mathrm{SHIP}^{-/-}$mice with those in the ilea of $\mathrm{SHIP}^{+/+}$ mice by immunocytochemistry for vimentin. Masson's

A

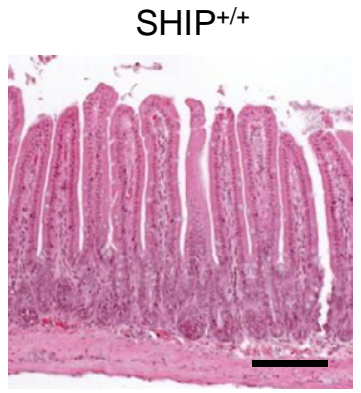

B
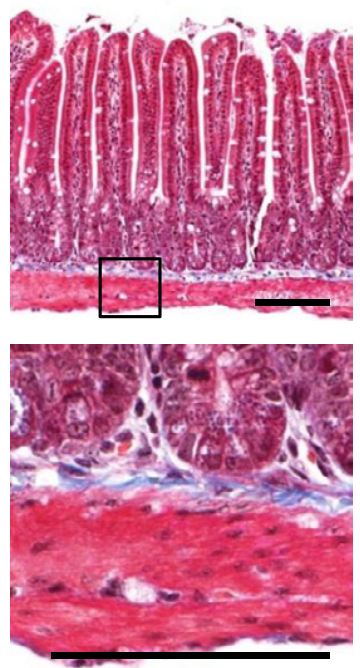

$\mathrm{C}$

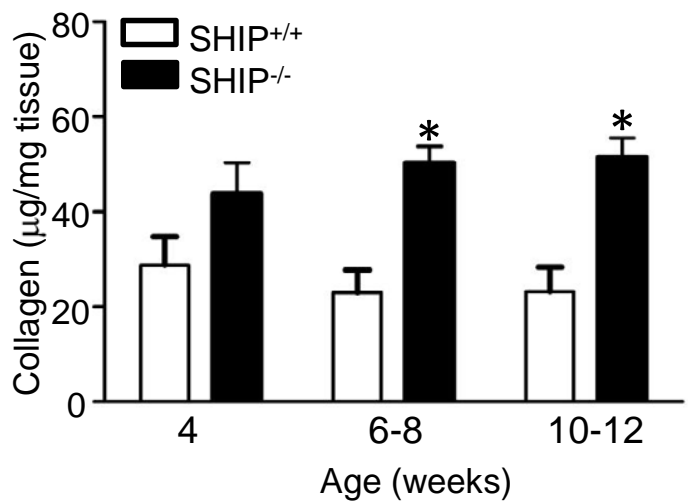

Figure 5. $\mathrm{SHIP}^{-/}$mice have elevated collagen deposition in their distal ilea, indicative of fibrosis. A: H\&E-stained horizontal sections of the distal ileum of 8 -week-old $\mathrm{SHIP}^{+/+}$(left) and $\mathrm{SHIP}^{-/}$(right) mice revealed a thickened muscle layer in SHIP $^{-/}$- mice. B: Masson's trichrome stain (blue) of adjacent sections from the same mice revealed increased collagen deposition. Insets: Higher magnifications show muscularis externa and muscularis mucosa and the presence of collagen between muscle layers (bottom). Scale bars $=100$ $\mu \mathrm{m}$. C: Sircol assays comparing collagen levels between $\mathrm{SHIP}^{+/+}$and $\mathrm{SHIP}^{-/}$ ilea. Bars represent the mean \pm SD for 6 to 12 mice at each age $\left({ }^{*} P<0.05\right)$. 
trichrome staining of $\mathrm{SHIP}^{+/+}$and $\mathrm{SHIP}^{-/-}$mouse ilea were performed at the same magnification used for vimentin immunocytochemistry to show the thickness of the muscle layers (Figure 6A). SHIP ${ }^{+/+}$mouse ilea have few vimentin ${ }^{+}$cells within the muscle layer, whereas $\mathrm{SHIP}^{-/}$ mouse ilea have abundant spindle-shaped vimentin ${ }^{+}$

A

$\mathrm{SHIP}^{+/+}$
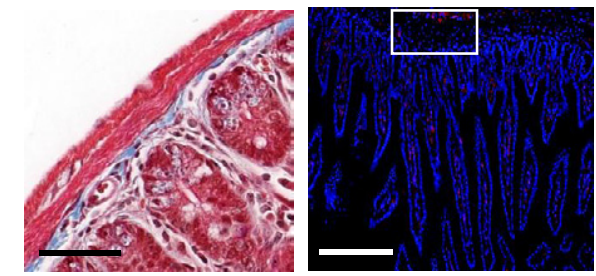

SHIP-
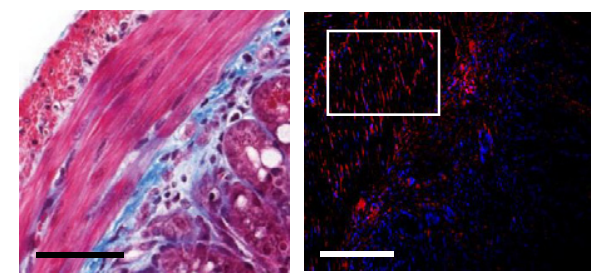

B

$\mathrm{SHIP}^{+/+}$

$\mathrm{SHIP}^{-1-}$
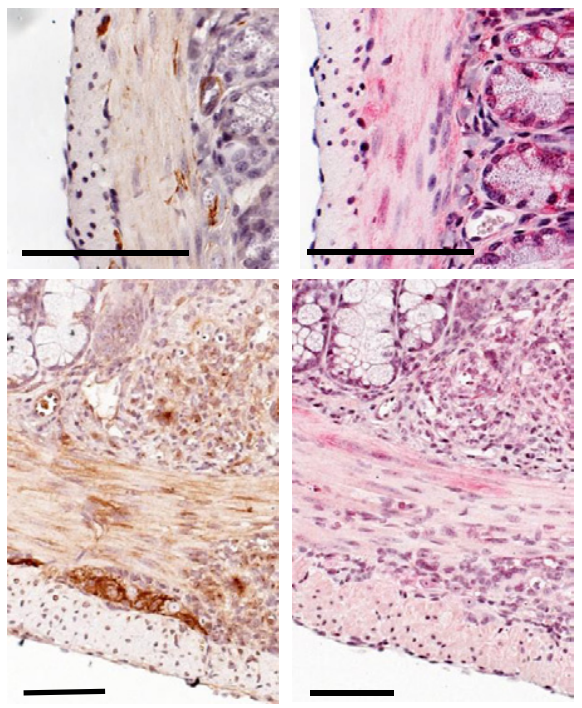

\section{C}

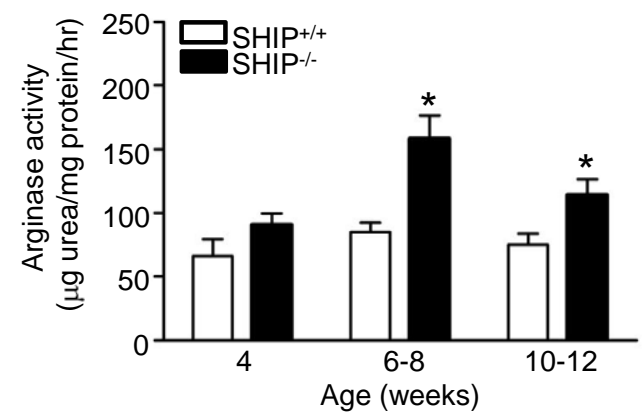

Figure 6. Increased collagen deposition correlates with increased fibroblasts, increased ArgI expression and activity, and decreased NO production in SHIP ${ }^{-/-}$mouse distal ilea. A: Masson's trichrome staining (blue, left) and anti-vimentin labeling (red, right: DAPI, blue) in ileal cross sections from $\mathrm{SHIP}^{+/+}$and $\mathrm{SHIP}^{-/}$mice. Scale bars $=50 \mu \mathrm{m}$. B: IHC analysis of ArgI (brown, left) and nitrotyrosine (pink/red, right) levels in serial sections from SHIP $^{+/+}$and SHIP ${ }^{-/}$mouse ilea (hematoxylin, blue). Scale bars $=100 \mu \mathrm{m}$. C: $\operatorname{ArgI}$ activity in $\mathrm{SHIP}^{+/+}$and $\mathrm{SHIP}^{-/-}$mouse ilea. Bars represent the mean \pm SD for 6 to 12 mice at each age $\left({ }^{*} P<0.05\right)$. cells within the muscle layer and in the submucosa (Figure 6A).

Given that Argl is up-regulated in vivo in $\mathrm{SHIP}^{-1-}$ mouse macrophages and is upstream of the L-proline required for collagen biosynthesis, we investigated Argl protein expression levels and arginase activity in the $\mathrm{SHIP}^{-/-}$ mouse ilea. The SHIP ${ }^{-1-}$ mouse ilea have increased Argl expression, including cells within immune cell aggregates, the submucosa, and the muscularis (Figure 6B). Arginases compete with $\mathrm{NO}$ synthases for their common substrate, L-arginine; therefore, increased Argl is predicted to reduce NO production in tissues. Indeed, in the $\mathrm{SHIP}^{-1-}$ mouse ilea, staining of nitrotyrosine (which is produced downstream of $\mathrm{NO}$ production) of serial sections was reduced compared with that of $\mathrm{SHIP}^{+/+}$littermate controls (Figure 6B). Arginase activity was also measured in ileal tissue homogenates to determine whether it was increased. SHIP ${ }^{-1-}$ mouse ilea had a 1.85fold increased arginase activity compared with $\mathrm{SHIP}^{+/+}$ littermate controls at the age of 6 to 8 weeks, and arginase activity was significantly higher at the age of 10 to 12 weeks (Figure 6C).

\section{Arginase Inhibition Reduced Collagen Deposition and Muscle Hyperplasia in $\mathrm{SHIP}^{-1}$ llea}

Increased arginase activity in the $\mathrm{SHIP}^{-/-}$mouse ilea correlated with increased collagen deposition; therefore, SHIP ${ }^{-1-}$ mice were treated with the arginase inhibitor, BEC, an arginine analogue that was previously used in other models of intestinal inflammation. ${ }^{31,32}$ Because the onset of increased arginase activity and collagen deposition in $\mathrm{SHIP}^{-1-}$ ilea occurred between the ages of 4 and 6 weeks, we treated $\mathrm{SHIP}^{-1-}$ mice daily with $100 \mu \mathrm{L}$ of $0.2 \% \mathrm{BEC}$ in water by oral gavage during this period. BEC treatment caused a $50 \%$ reduction in arginase activity compared with untreated 6-week-old SHIP ${ }^{-1-}$ mice (Figure 7A), and Argl protein expression was also decreased (Figure 7B). Immune cell infiltrates were still present in the BEC-treated mice and were not significantly reduced relative to untreated SHIP ${ }^{-1-}$ controls (Figure $7 \mathrm{C}$ ). BEC-treated $\mathrm{SHIP}^{-1-}$ mice had decreased collagen deposition, evident from reduced Masson's trichrome staining (Figure 7D), and ileal collagen was also reduced by $25 \%$ compared with untreated $\mathrm{SHIP}^{--}$mice in Sircol assays (Figure 7E). The thickness of the muscle layers was reduced in BEC-treated $\mathrm{SHIP}^{-1-}$ mice relative to untreated $\mathrm{SHIP}^{-1-}$ mice (Figure 7E).

\section{Discussion}

The current treatment of CD includes therapies to reduce intestinal inflammation, improving quality of life for patients. ${ }^{33}$ Despite improvements in therapies reducing inflammation, fibrosis remains a serious complication of disease. ${ }^{34}$ Research studying intestinal fibrosis has been challenging, in part, because of a lack of suitable animal 
A

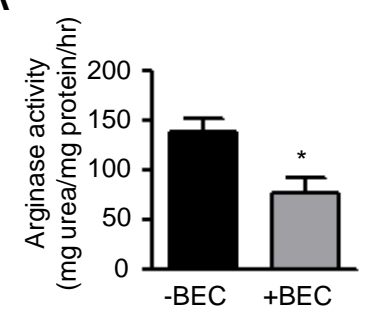

C

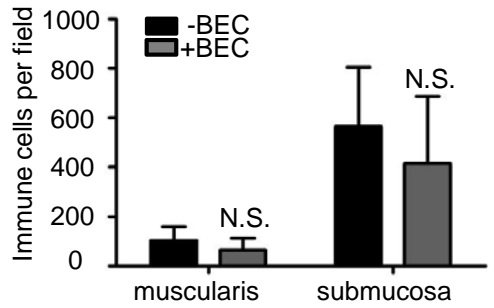

B
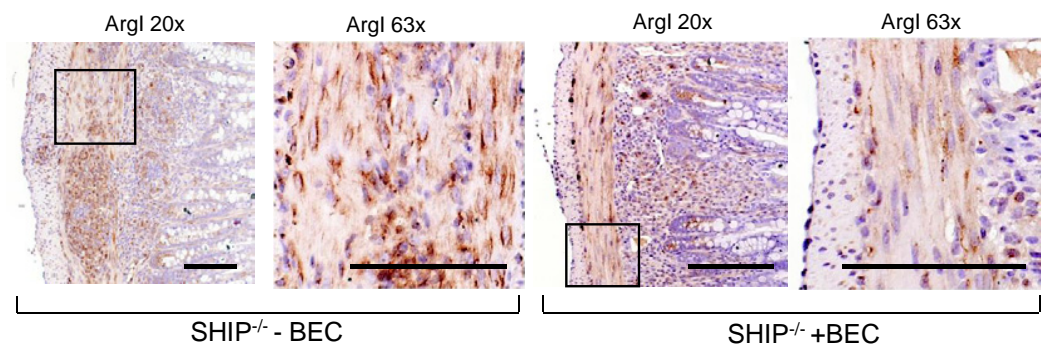

$\mathrm{SHIP}^{-/}+\mathrm{BEC}$

D
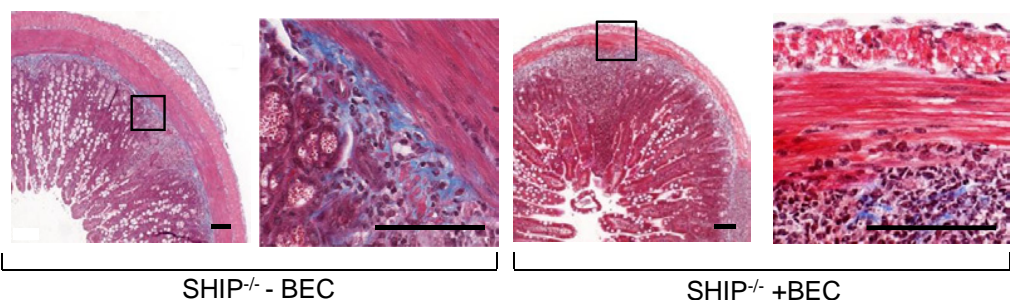

$E$
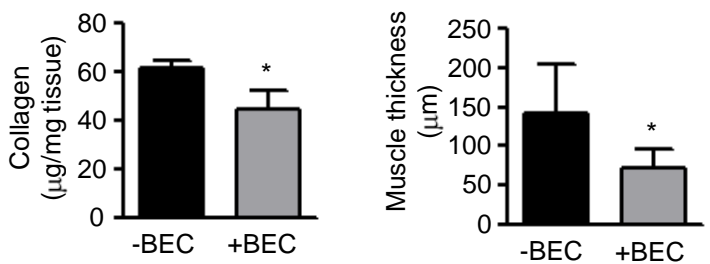

Figure 7. Inhibition of ArgI activity reduces collagen deposition and muscle hyperplasia in $\mathrm{SHIP}^{-/-}{ }_{\text {ilea. }} \mathrm{SHIP}^{-/-}$mice were administered $0.2 \%$ BEC in distilled water by oral gavage daily from the age of 4 to 6 weeks. A: Arginase activity from ilea of untreated $(-\mathrm{BEC})$ and $\mathrm{BEC}$-treated $(+\mathrm{BEC})$ SHIP ${ }^{-/-}$mice $\left({ }^{*} P<0.02\right)$. B: IHC labeling of ArgI in ileal cross sections of 6 -week-old -BEC and +BEC SHIP ${ }^{-1-}$ mice. Insets: Regions of magnification $(\times 63)$. Scale bar $=100 \mu$ m. C: Assessment of immune cell infiltrates within the muscularis and submucosa of -BEC and $+\mathrm{BEC} \mathrm{SHIP}^{-/-}$mice. The nuclei of infiltrating immune cells were counted. Bars represent the mean \pm SD of four representative fields, counted at $\times 20$ magnification in ileal cross sections from six mice from each group. N.S. indicates not significant. D: Masson's trichrome stain (blue) of ileal sections of -BEC and +BEC SHIP ${ }^{-/}$mice. Scale bar $=100 \mu \mathrm{m}$. E: Sircol assays for soluble collagen (left) and thickness of muscle layer (right) in $\mathrm{SHIP}^{-/}$mouse ilea, for $-\mathrm{BEC}$ or $+\mathrm{BEC}$. Bars represent the mean $\pm \mathrm{SD}(n=7)$ performed in three independent experiments $\left({ }^{*} P<0.001\right)$.

models. Herein, we report that the $\mathrm{SHIP}^{-1-}$ mouse is a model of spontaneous intestinal inflammation that shares key features with CD. More importantly, these mice develop fibrosis, characterized by thickening of the muscle layers, collagen deposition, and fibroblast accumulation in the distal ileum (Figures 5 and 6).

There are several inducible murine models of intestinal fibrosis. Intestinal fibrosis can be induced in mouse colon and cecum by chronic Salmonella enterica infection ${ }^{19}$ and in the colon by overexpression of transforming growth factor- $\beta 1^{20}$ or monocyte chemoattractant protein- $1^{21}$ or by repeated induction of colitis by trinitrobenzene sulfonic acid. ${ }^{22}$ These models do not cause fibrosis in the ileum, where it is most frequently found in patients with $C D$, and do not provide insight into spontaneous development of intestinal fibrosis. There are two genetic mouse models of spontaneous ileal inflammation. The tumor necrosis factor $^{\triangle A R E}$ mouse develops ileal inflammation beginning before the age of 4 weeks, with inflammatory infiltrates in the submucosa containing scattered neutrophils and collections of histiocytes but do not display muscle thickening or collagen deposition. ${ }^{23}$ The SAMP1/ YitFc mouse develops ileal inflammation with thickened circular muscle and collagen deposition in the submucosa and has perianal fistulae. ${ }^{24}$ Fibrosis develops slowly over 40 weeks in these mice, and the multigenic changes that cause this phenotype remain undefined.

Features reminiscent of $\mathrm{CD}$ in the $\mathrm{SHIP}^{-1-}$ mouse include both inflammatory and fibrotic components. CD is characterized by discontinuous inflammation primarily in the distal ileum, ${ }^{35}$ and $\mathrm{SHIP}^{-1-}$ mouse inflammation is discontinuous and restricted to the distal third of the ileum (Figure 1B). Sites of inflammation in patients with $\mathrm{CD}$ are dominated by neutrophils, ${ }^{36}$ and abundant neutrophils are present in the $\mathrm{SHIP}^{--}$ileum (Figure 3). An additional feature of $\mathrm{CD}$ is the formation of rudimentary granulomata in the ileum, ${ }^{37}$ and a diagnostic feature of the disease is the presence of multinucleated giant cells in the inflamed ileum. ${ }^{38,39}$ Similarly, $\mathrm{SHIP}^{-1-}$ mice also have poorly formed granuloma containing multinucleated giant cells within the ileum (Figure 2B). Fibrotic features of $C D$, such as muscle hyperplasia and collagen deposition, ${ }^{40}$ are also present in our model (Figure 5). Transmural fibroblast accumulation that occurs during intestinal fibrosis in patients with $C D$ is also apparent in our model as an increase in vimentin ${ }^{+}$cells (Figure 6A).

CD has traditionally been considered to be a Th1- and Th17-mediated disease based on increased production of interferon- $\gamma, \mathrm{IL}-12 \mathrm{p} 70$, and IL-23 in the early phases of inflammation. ${ }^{2,41-43}$ Recently, the SHIP ${ }^{-1-}$ mouse was re- 
ported to be Th2 skewed, ${ }^{44}$ which was attributed to hyperactive basophils producing IL $-4 .{ }^{45}$ Unlike the inflammatory response characterized during active $\mathrm{CD}$, fibrosis is a Th2-driven process. ${ }^{46} \mathrm{IL}-4$ and IL-13 stimulate type I collagen gene expression (Col1a2) ${ }^{47}$ and collagen production by fibroblasts. ${ }^{47,48}$ The inflamed and fibrotic SHIP ${ }^{-1-}$ mouse ilea express a mixed Th2 and Th17 cytokine profile, with significantly increased production of IL-4, IL-13, and IL-23 (Figure 4). Alternatively activated macrophages, fibroblasts, and dysregulated Th2 and Th17 cytokine production have recently been suggested as the critical players in the development of an exaggerated healing response that leads to fibrosis. ${ }^{49}$ The $\mathrm{SHIP}^{-1-}$ mouse has a myeloproliferative disorder and alternatively activated macrophages, abundant fibroblasts, and increased Th2 and Th17 cytokine responses that may cooperate to cause the dramatic ileal fibrosis in the $\mathrm{SHIP}^{-/-}$mouse.

We recently found that PI3K, and specifically PI3Kp1108, activity is required for robust expression of Argl in response to IL-4. ${ }^{50}$ Increased Argl expression and arginase activity are features of murine alternatively activated macrophages ${ }^{26}$; in vivo $\mathrm{SHIP}^{-/}$mouse macrophages, including intestinal macrophages, are alternatively activated and constitutively express Argl. ${ }^{27,51}$ On examination, Argl expression and arginase activity were up-regulated in the distal ilea of $\mathrm{SHIP}^{-/-}$mice (Figure 6). Arginase could play an indirect role in the SHIP ${ }^{-/-}$mouse ileal fibrosis by affecting inflammation. Alternatively, arginase could play a direct role in promoting fibrosis by increasing proline production, which is required for collagen biosynthesis, and/or by increasing ornithine production, which is metabolized by ornithine decarboxylase to produce polyamines that promote cell cycle progression and could lead to muscle hyperplasia. ${ }^{52}$ Based on this, we hypothesized that arginase inhibition could reduce intestinal fibrosis. Blocking arginase activity in the intestine with $\mathrm{BEC}$ has exacerbated inflammation, including immune cell infiltration, during Citrobacter rodentiuminduced colitis, ${ }^{31}$ but limits disease during Helicobacter pylori infection by increasing NO-mediated killing of the pathogen. ${ }^{32}$ In our $\mathrm{SHIP}^{-/}$mouse genetic model of intestinal inflammation, BEC treatment reduced arginase activity and expression in the $\mathrm{SHIP}^{--}$mouse ilea (Figure 7A) but had no impact on the number of immune cell infiltrates or immune cell aggregates present in the $\mathrm{SHIP}^{-/}$ mouse ilea (Figure 7D). More importantly, BEC treatment reduced fibrosis, collagen deposition, and muscle hyperplasia in the SHIP ${ }^{-/-}$mouse ilea (Figure 7E).

SHIP acts by negatively regulating signaling through the PI3K pathway, which is reported to be an important signaling pathway in inflammatory bowel disease. ${ }^{53}$ Interestingly, human SHIP is encoded in the 2 q37 region of human chromosome 2, where a polymorphism that is associated with early-onset inflammatory bowel disease has recently been described. ${ }^{54}$ Our study identifies SHIP deficiency as a genetic cause of murine intestinal inflammation with CD-like features, highlighting the importance of the SHIP and PI3K pathway as regulators of intestinal homeostasis. The power of this model of CD is that it accurately and consistently recapitulates both the ileal localization of inflammation and the ileal fibrosis that occurs in some patients with $\mathrm{CD}$. Argl activity correlates with fibrosis in two murine models of lung fibrosis, and arginase expression is significantly higher in resected gut tissues from patients with $C D{ }^{57}$ Arginase inhibition reduced the fibrosis that we observed in the $\mathrm{SHIP}^{-1-}$ mouse ileum, identifying arginase as a potential target for the treatment of intestinal fibrosis.

\section{References}

1. Bernstein CN, Wajda A, Svenson LW, MacKenzie A, Koehoorn M, Jackson M, Fedorak R, Israel D, Blanchard JF: The epidemiology of inflammatory bowel disease in Canada: a population-based study. Am J Gastroenterol 2006, 101:1559-1568

2. Brand S: Crohn's disease: Th1, Th17 or both? the change of a paradigm: new immunological and genetic insights implicate Th17 cells in the pathogenesis of Crohn's disease. Gut 2009, 58:11521167

3. Louis E, Collard A, Oger AF, Degroote E, Aboul Nasr El Yafi FA, Belaiche J: Behaviour of Crohn's disease according to the Vienna classification: changing pattern over the course of the disease. Gut 2001, 49:777-782

4. Burke JP, Mulsow JJ, O'Keane C, Docherty NG, Watson RW O'Connell PR: Fibrogenesis in Crohn's disease. Am J Gastroenterol 2007, 102:439-448

5. Van Assche G, Geboes K, Rutgeerts P: Medical therapy for Crohn's disease strictures. Inflamm Bowel Dis 2004, 10:55-60

6. Sorrentino D, Terrosu G, Avellini C: Infliximab in Crohn's disease: a look at the (not so distant) future. Dig Liver Dis 2008, 40(Suppl 2):S229-S235

7. Sorrentino D: Role of biologics and other therapies in stricturing Crohn's disease: what have we learnt so far? Digestion 2008, 77: $38-47$

8. Burke JP, Ferrante M, Dejaegher K, Watson RW, Docherty NG, De Hertogh G, Vermeire S, Rutgeerts P, D'Hoore A, Penninckx F, Geboes K, Van Assche G, O'Connell PR: Transcriptomic analysis of intestinal fibrosis-associated gene expression in response to medical therapy in Crohn's disease. Inflamm Bowel Dis 2008, 14:1197-1204

9. Rieder F, Fiocchi C: First international summit on fibrosis in intestinal inflammation: mechanisms and biological therapies. Fibrogenesis Tissue Repair 2010, 3:22

10. Szabò H, Fiorino G, Spinelli A, Rovida S, Repici A, Malesci AC, Danese S: Review article: anti-fibrotic agents for the treatment of Crohn's disease - lessons learnt from other diseases. Aliment Pharmacol Ther 2010, 31:189-201

11. Aumailley M, Gayraud B: Structure and biological activity of the extracellular matrix. J Mol Med 1998, 76:253-265

12. Rieder F, Fiocchi C: Intestinal fibrosis in IBD: a dynamic, multifactorial process. Nat Rev Gastroenterol Hepatol 2009, 6:228-235

13. Bhogal RK, Stoica CM, McGaha TL, Bona CA: Molecular aspects of regulation of collagen gene expression in fibrosis. J Clin Immunol 2005, 25:592-603

14. Regan MC, Flavin BM, Fitzpatrick JM, O'Connell PR: Stricture formation in Crohn's disease: the role of intestinal fibroblasts. Ann Surg 2000, 231:46-50

15. Mizoguchi A, Mizoguchi E: Animal models of IBD: linkage to human disease. Curr Opin Pharmacol 2010, 10:578-587

16. Nell S, Suerbaum S, Josenhans C: The impact of the microbiota on the pathogenesis of IBD: lessons from mouse infection models. Nat Rev Microbiol 2010, 8:564-577

17. Flier SN, Tanjore H, Kokkotou EG, Sugimoto H, Zeisberg M, Kalluri R Identification of epithelial to mesenchymal transition as a novel source of fibroblasts in intestinal fibrosis. J Biol Chem 2010, 285: 20202-20212

18. Rigby RJ, Hunt MR, Scull BP, Simmons JG, Speck KE, Helmrath MA, Lund PK: A new animal model of postsurgical bowel inflammation and fibrosis: the effect of commensal microflora. Gut 2009, 58:1104-1112

19. GrassI GA, Valdez Y, Bergstrom KS, Vallance BA, Finlay BB: Chronic enteric salmonella infection in mice leads to severe and persistent intestinal fibrosis. Gastroenterology 2008, 134:768-780 
20. Vallance BA, Gunawan MI, Hewlett B, Bercik P, Van Kampen C, Galeazzi F, Sime PJ, Gauldie J, Collins SM: TGF-beta1 gene transfer to the mouse colon leads to intestinal fibrosis. Am J Physiol Gastrointest Liver Physiol 2005, 289:G116-G128

21. Motomura Y, Khan WI, El-Sharkawy RT, Verma-Gandhu M, Verdu EF, Gauldie J, Collins SM: Induction of a fibrogenic response in mouse colon by overexpression of monocyte chemoattractant protein 1. Gut 2006, 55:662-670

22. Lawrance IC, Wu F, Leite AZ, Willis J, West GA, Fiocchi C, Chakravarti $S$ : A murine model of chronic inflammation-induced intestinal fibrosis down-regulated by antisense NF-kappa B. Gastroenterology 2003 , 125:1750-1761

23. Kontoyiannis D, Boulougouris G, Manoloukos M, Armaka M, Apostolaki M, Pizarro T, Kotlyarov A, Forster I, Flavell R, Gaestel M, Tsichlis P, Cominelli F, Kollias G: Genetic dissection of the cellular pathways and signaling mechanisms in modeled tumor necrosis factor-induced Crohn's-like inflammatory bowel disease. J Exp Med 2002, 196:15631574

24. Rivera-Nieves J, Bamias G, Vidrich A, Marini M, Pizarro TT, McDuffie MJ, Moskaluk CA, Cohn SM, Cominelli F: Emergence of perianal fistulizing disease in the SAMP1/YitFc mouse, a spontaneous model of chronic ileitis. Gastroenterology 2003, 124:972-982

25. Helgason CD, Damen JE, Rosten P, Grewal R, Sorensen P, Chappel SM, Borowski A, Jirik F, Krystal G, Humphries RK: Targeted disruption of SHIP leads to hemopoietic perturbations, lung pathology, and a shortened life span. Genes Dev 1998, 12:1610-1620

26. Sly LM, Ho V, Antignano F, Ruschmann J, Hamilton M, Lam V, Rauh MJ, Krystal G: The role of SHIP in macrophages. Front Biosci 2007 12:2836-2848

27. Rauh MJ, Ho V, Pereira C, Sham A, Sly LM, Lam V, Huxham L, Minchinton Al, Mui A, Krystal G: SHIP represses the generation of alternatively activated macrophages. Immunity 2005, 23:361-374

28. Kerr WG, Park MY, Maubert M, Engelman RW: SHIP deficiency causes Crohn's disease-like ileitis. Gut 2011, 60:177-188

29. Ho VW, Sly LM: Derivation and characterization of murine alternatively activated (M2) macrophages. Methods Mol Biol 2009, 531:173-185

30. Kim NN, Cox JD, Baggio RF, Emig FA, Mistry SK, Harper SL, Speicher DW, Morris SM Jr, Ash DE, Traish A, Christianson DW: Probing erectile function: $\mathrm{s}$-(2-boronoethyl)-L-cysteine binds to arginase as a transition state analogue and enhances smooth muscle relaxation in human penile corpus cavernosum. Biochemistry 2001, 40:26782688

31. Gobert AP, Cheng Y, Akhtar M, Mersey BD, Blumberg DR, Cross RK, Chaturvedi R, Drachenberg CB, Boucher JL, Hacker A, Casero RA Jr Wilson KT: Protective role of arginase in a mouse model of colitis. J Immunol 2004, 173:2109-2117

32. Lewis ND, Asim M, Barry DP, Singh K, de Sablet T, Boucher JL, Gobert AP, Chaturvedi R, Wilson KT: Arginase II restricts host defense to Helicobacter pylori by attenuating inducible nitric oxide synthase translation in macrophages. J Immunol 2010, 184:25722582

33. Podolsky DK: Inflammatory bowel disease. N Engl J Med 2002 , 347:417-429

34. Cosnes J, Nion-Larmurier I, Beaugerie L, Afchain P, Tiret E, Gendre JP: Impact of the increasing use of immunosuppressants in Crohn's disease on the need for intestinal surgery. Gut 2005, 54:237-241

35. Lennard-Jones JE: Classification of inflammatory bowel disease. Scand J Gastroenterol Suppl 1989, 170:2-6; discussion, 16-19

36. Hanauer SB: Inflammatory bowel disease: epidemiology, pathogenesis, and therapeutic opportunities. Inflamm Bowel Dis 2006 12(Suppl 1):S3-S9

37. Xavier RJ, Podolsky DK: Unravelling the pathogenesis of inflammatory bowel disease. Nature 2007, 448:427-434

38. Adams DO: The granulomatous inflammatory response: a review. Am J Pathol 1976, 84:164-192
39. Fais S, Pallone F: Inability of normal human intestinal macrophages to form multinucleated giant cells in response to cytokines. Gut 1995 , 37:798-801

40. Graham MF, Diegelmann RF, Elson CO, Lindblad WJ, Gotschalk N, Gay S, Gay R: Collagen content and types in the intestinal strictures of Crohn's disease. Gastroenterology 1988, 94:257-265

41. Kugathasan S, Saubermann LJ, Smith L, Kou D, Itoh J, Binion DG, Levine AD, Blumberg RS, Fiocchi C: Mucosal T-cell immunoregulation varies in early and late inflammatory bowel disease. Gut 2007 56:1696-1705

42. Fuss IJ, Becker C, Yang Z, Groden C, Hornung RL, Heller F, Neurath MF, Strober W, Mannon PJ: Both IL-12p70 and IL-23 are synthesized during active Crohn's disease and are down-regulated by treatment with anti-IL-12 p40 monoclonal antibody. Inflamm Bowel Dis 2006, 12:9-15

43. Monteleone G, Trapasso F, Parrello T, Biancone L, Stella A, Iuliano R, Luzza F, Fusco A, Pallone F: Bioactive IL-18 expression is up-regulated in Crohn's disease. J Immunol 1999, 163:143-147

44. Kuroda E, Antignano F, Ho VW, Hughes MR, Ruschmann J, Lam V, Kawakami T, Kerr WG, McNagny KM, Sly LM, Krystal G: SHIP represses Th2 skewing by inhibiting IL-4 production from basophils. J Immunol 2011, 186:323-332

45. Kuroda E, Ho V, Ruschmann J, Antignano F, Hamilton M, Rauh MJ, Antov A, Flavell RA, Sly LM, Krystal G: SHIP represses the generation of IL-3-induced M2 macrophages by inhibiting IL-4 production from basophils. J Immunol 2009, 183:3652-3660

46. Wynn TA: Fibrotic disease and the $\mathrm{T}(\mathrm{H}) 1 / \mathrm{T}(\mathrm{H}) 2$ paradigm. Nat Rev Immunol 2004, 4:583-594

47. Gillery P, Fertin C, Nicolas JF, Chastang F, Kalis B, Banchereau J, Maquart FX: Interleukin-4 stimulates collagen gene expression in human fibroblast monolayer cultures: potential role in fibrosis. FEBS Lett 1992, 302:231-234

48. Postlethwaite AE, Holness MA, Katai H, Raghow R: Human fibroblasts synthesize elevated levels of extracellular matrix proteins in response to interleukin 4. J Clin Invest 1992, 90:1479-1485

49. Barron L, Wynn TA: Fibrosis is regulated by Th2 and Th17 responses and by dynamic interactions between fibroblasts and macrophages. Am J Physiol Gastrointest Liver Physiol 2011, 300:G723-8

50. Weisser SB, McLarren KW, Voglmaier N, van Netten-Thomas CJ, Antov A, Flavell RA, LM Sly: Alternative activation of macrophages by IL-4 requires SHIP degradation. Eur J Immunol 2011 Mar 21. doi: 10.1002/eji.201041105.

51. Bishop JL, Sly LM, Krystal G, Finlay BB: The inositol phosphatase SHIP controls Salmonella enterica serovar Typhimurium infection in vivo. Infect Immun 2008, 76:2913-2922

52. Casero RA Jr, Marton LJ: Targeting polyamine metabolism and function in cancer and other hyperproliferative diseases. Nat Rev Drug Discov 2007, 6:373-390

53. Wei J, Feng J: Signaling pathways associated with inflammatory bowel disease. Recent Pat Inflamm Allergy Drug Discov 2010, 4:105-117

54. Imielinski M, Baldassano RN, Griffiths A, Russell RK, Annese V, Dubinsky $\mathrm{M}$, et al: Common variants at five new loci associated with earlyonset inflammatory bowel disease. Nat Genet 2009, 41:1335-1340

55. Endo M, Oyadomari S, Terasaki Y, Takeya M, Suga M, Mori M, Gotoh $\mathrm{T}$ : Induction of arginase I and II in bleomycin-induced fibrosis of mouse lung. Am J Physiol Lung Cell Mol Physiol 2003, 285:L313L321

56. Mora AL, Torres-Gonzalez E, Rojas M, Corredor C, Ritzenthaler J, Xu $\mathrm{J}$, Roman J, Brigham K, Stecenko A: Activation of alveolar macrophages via the alternative pathway in herpesvirus-induced lung fibrosis. Am J Respir Cell Mol Biol 2006, 35:466-473

57. Horowitz S, Binion DG, Nelson VM, Kanaa Y, Javadi P, Lazarova Z, Andrekopoulos C, Kalyanaraman B, Otterson MF, Rafiee P: Increased arginase activity and endothelial dysfunction in human inflammatory bowel disease. Am J Physiol Gastrointest Liver Physiol 2007, 292: G1323-G1336 